Research article

\title{
PERFORMANCE OF ASSAYS FOR TESTING ANTIBODIES AGAINST PORCINE REPRODUCTIVE AND RESPIRATORY SYNDROME VIRUS IN SERA COLLECTED FROM SWINE FARMS IN A REGION WITH AN EXTREME VIRUS HETEROGENEITY
}

\author{
KARNIYCHUK U Uladzimir ${ }^{1 *}$, NAUWYNCK J Hans ${ }^{2}$ \\ ${ }^{1}$ Department of Pathology \& Molecular Medicine, McMaster Immunology Research Centre, McMaster \\ University, 1280 Main Street West, Hamilton, ON L8S 4K1, Canada; ${ }^{2}$ Laboratory of Virology, Faculty of \\ Veterinary Medicine, Ghent University, Salisburylaan 133, 9820 Merelbeke, Belgium
}

(Received 18 January 2014; Accepted 07 February 2014)

\begin{abstract}
Porcine reproductive and respiratory syndrome is the most economically important viral disease in the swine industry worldwide. Porcine reproductive and respiratory syndrome virus (PRRSV) strains are classified into two distinct genotypes, the European genotype and the North American genotype. The European PRRSV genotype has been divided into three subtypes: a pan-European subtype 1 and East European subtypes 2 and 3. The aim of this study was to evaluate the performance of commercial and homemade serological assays to test field sera from a geographical region with an extreme PRRSV heterogeneity. Belarus became the country of choice for sample collection because heterologous PRRSV strains of all known European subtypes circulate in this country. Sera from Belarusian swine farms were tested in immunoperoxidase monolayer assays based on pan-European subtype 1, East European subtype 3 and North American strains as antigens and commercial enzyme-linked immunosorbent assays (IDEXX and INGEZIM). The obtained results suggest that none of the serological tools for PRRSV diagnosis can guarantee a flawless detection of antibodies at the individual animal level. Considering heterogeneity of recently isolated European PRRSV strains the problem can be relevant in many countries.
\end{abstract}

Key words: porcine reproductive and respiratory syndrome virus; serology; diagnosis; Belarus

\section{INTRODUCTION}

Porcine reproductive and respiratory syndrome is the most economically important viral disease in the swine industry worldwide. Porcine reproductive and respiratory syndrome virus (PRRSV) strains are classified into two distinct genotypes, the European genotype and the North American genotype [1]. The European PRRSV genotype has been divided into three subtypes: a pan-European subtype 1 (the prototype is the Lelystad virus, LV) and East European subtypes 2 and 3 [2]. Recently, a previously unknown East European subtype 3 PRRSV strain (Lena) from Belarus has been isolated and its

*Corresponding author: e-mail: karniyu@memaster.ca 
genetic, antigenic and pathogenic properties have been described [3].

An immunoperoxidase monolayer assay (IPMA) and an enzyme-linked immunosorbent assay (ELISA) are commonly used to detect PRRSV-specific antibodies. It is considered that the IPMA is one of the most reliable serological tools [4]. In addition, IDEXX PRRS 2XR Antibody Test (IDEXX 2XR ELISA) (IDEXX Laboratories, Westbrook, ME, USA), the enzyme-linked immunosorbent assay, became the standard for monitoring the serological status of swine herds [5]. At present, IDEXX 2XR ELISA is the only test used in Belarus and some other East European countries to detect antibodies against PRRSV. An enzyme-linked immunosorbent assays, IDEXX PRRS X3 Antibody Test (IDEXX 3X ELISA) (IDEXX Laboratories, Westbrook, ME, USA) and INGEZIM PRRS Universal kit (INGEZIM ELISA) (INGENASA, Madrid, Spain) are also available on the market. All these ELISA kits are indirect assays based on viral nucleocapsid antigens belonging to the pan-European subtype 1 and North American PRRSV strains. An antigenic heterogeneity between pan-European subtype 1 and North American PRRSV strains has been described earlier [6-8]. Some level of antigenic heterogeneity between East European subtype 3 and pan-European subtype 1 strains has also been reported [3]. The aim of the present study was to evaluate several serological assays to test antibodies against PRRSV in serum samples collected from swine farms in a region with a high degree of PRRSV heterogeneity. Belarus became the country of choice for sample collection because different heterologous PRRSV strains of the all known European sub-types circulate in this region [2,9]. Serum samples were tested applying IPMAs based on PRRSV Lena, LV and VR-2332 strains as antigens and commercial IDEXX 2XR ELISA, IDEXX 3X ELISA and INGEZIM ELISA.

\section{MATERIALS AND METHODS}

Experimental serum samples were collected in a previous study (from 9 pigs after oronasal inoculation with $10^{6} \mathrm{TCID}_{50} /$ pig of PRRSV Lena, [3]) and were tested applying commercial ELISAs. Afterwards, 269 field samples from Belarus were tested in IPMAs and commercial ELISAs. Field samples from sows were derived from 15 Belarusian farms with a history of respiratory and reproductive disorders. Vaccination against PRRSV was never applied on those farms. Porcine reproductive and respiratory syndrome virus-specific antibodies were detected with the IPMA on MARC-145 cells infected with PRRSV as previously described [10]. The reference pan-European subtype 1 PRRSV LV [4], East European subtype 3 PRRSV Lena and reference North American PRRSV VR-2332 [11] were used as IPMA antigens. All serum samples were tested in duplicate. The commercial IDEXX 2XR ELISA was used to detect PRRSV antibodies in experimental antisera and field samples according to the manual. To test sera in the IDEXX 3X ELISA and INGEZIM ELISA, samples were sent to IDEXX (IDEXX Livestock and Poultry Diagnostics, Uppsala, Sweden) and INGEZIME (Inmunología y Genética Aplicada S.A., Madrid, Spain), respectively.

The sensitivity and specificity of serological diagnostic tests are based on a "gold standard". There is currently no recognized gold standard for the detection of PRRSV antibodies. In the present study, the IPMA status of samples was used as the stan- 
dard against which commercial ELISAs were evaluated. The selection of the diagnostic standard was based on several reasons. First, previous results obtained in the authors' study clearly demonstrate the high sensitivity and specificity of IPMAs [3]. All serum samples collected from 27 PRRSV-inoculated pigs were positive for virus-specific antibodies at 7-10 days post-inoculation. In contrast, all samples collected before or at three days post-inoculation were negative. Second, the IPMA allowed to use three different PRRSV strains as antigens (LV: pan-European subtype 1 PRRSV; Lena: East European subtype 3 PRRSV; and VR-2332: North American PRRSV) while all commercial ELISAs are based on only two PRRSV strains (pan-European subtype 1 PRRSV and North American PRRSV). Finally, the use of a primary serum dilution 1/10 in a dilution buffer for IPMA tests (in the present study serial sample dilutions $1 / 10,1 / 40$ and 1/160 were used) hypothetically allows a more sensitive detection of antibodies than ELISAs do. Test sample dilutions used for the IDEXX 2XR ELISA, IDEXX 3X ELISA and INGEZIM ELISA are 1/40,1/40 and 1/100, respectively. Serum samples were regarded as IPMA-positive $\left(\mathrm{IPMA}^{+}\right.$) when it showed a specific antigen staining (Figure 1) in at least one of IPMAs (LV, Lena, VR-3223). Upon testing field sera, the sensitivity and specificity of the ELISAs were calculated as follows: sensitivity $=$ [number of IPMA ${ }^{+}$ sera] / [number of $\mathrm{IPMA}^{+}$sera + number of ELISA false negative sera]; specificity $=[$ number of IPMA sera] / [number of IPMA sera + number of ELISA false positive sera].

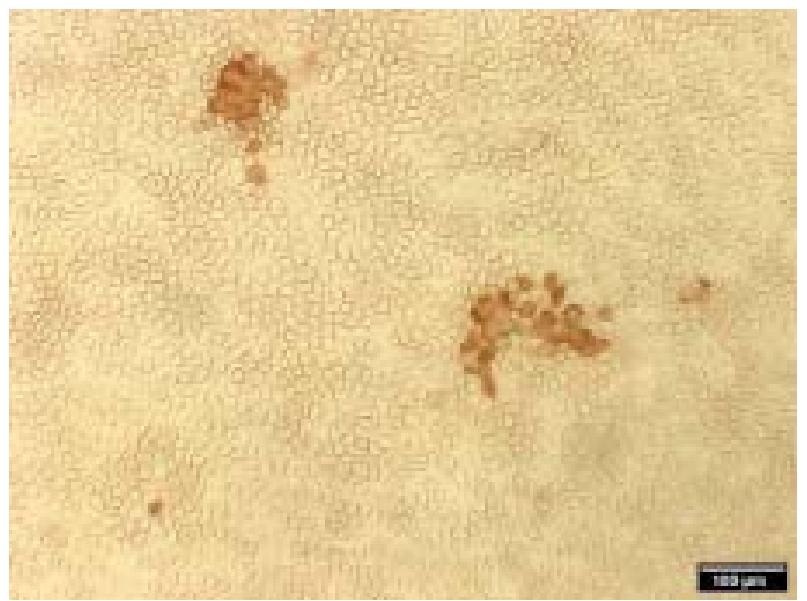

Figure 1. IPMA staining. PRRSV antigens (brown staining) within the cytoplasm of MARC-145 cells. Cells were seeded in 96-well cell culture plates, inoculated with $50 \mu \mathrm{l}$ of PRRSV (Lelystad, Lena or VR-2332) and incubated for $18 \mathrm{~h}\left(37^{\circ} \mathrm{C}, 5 \% \mathrm{CO}_{2}\right)$. Then, the culture medium was removed, and cells were washed in PBS and dried at $37^{\circ} \mathrm{C}$ for $1 \mathrm{~h}$. The plates were kept at $-70^{\circ} \mathrm{C}$ until use. Plates were thawed and then fixed in 4\% paraformaldehyde for $10 \mathrm{~min}$. The paraformaldehyde was removed, the cells were washed twice with PBS and a solution of $1 \% \mathrm{H}_{2} \mathrm{O}_{2}$ in methanol was added. Plates were washed twice with PBS and serial dilutions of the sera were added. Sera were incubated for $1 \mathrm{~h}$ at $37^{\circ} \mathrm{C}$. Plates were washed three times with PBS plus $1 \%$ Tween 80 and $50 \mu$ l of $1 / 250$ rabbit anti-swine IgG HRP-conjugated antibodies (Dako) was added to each well. After incubation at $37^{\circ} \mathrm{C}$ for $1 \mathrm{~h}$, plates were washed three times and $50 \mu \mathrm{l}$ of a substrate solution of 3-amino-9-ethylcarbazole in $0.05 \mathrm{M}$ acetate buffer, $\mathrm{pH} 5$, with $0.05 \%$ $\mathrm{H}_{2} \mathrm{O}_{2}$ was added to each well, and incubated at room temperature for $20 \mathrm{~min}$. Then, the reaction was blocked by replacing the substrate by acetate buffer and the results were determined by examination with a microscope 


\section{RESULTS}

Previously, the good sensitivity of ELISAs has been reported testing experimental panEuropean subtype 1 PRRSV antisera $[12,13]$. Therefore, prior to testing field samples, experimental antisera from pigs inoculated with East European subtype 3 PRRSV Lena have been tested using three commercial ELISAs. All tests were able to determine PRRSV-specific antibodies during the course of infection (Figure 2). However, results differed at 7 days post-inoculation. At this time point, IDEXX 2XR ELISA was able to detect antibodies in 5 samples out of 9, IDEXX 3X ELISA in 1 sample out of 9, while INGEZIM ELISA was not able to detect antibodies. In our previous study, when same serum samples have been tested in the homologous Lena IPMA, 6 sera out of 9 were positive [3]. One serum collected before inoculation of the pig gave a positive result in the IDEXX 2XR ELISA. In this sample the IPMA or IDEXX 3X ELISA and INGEZIM ELISA antibodies were not detected. The negative result of virus isolation and titration indicated that this animal had not previously been infected with PRRSV (false positive reaction).

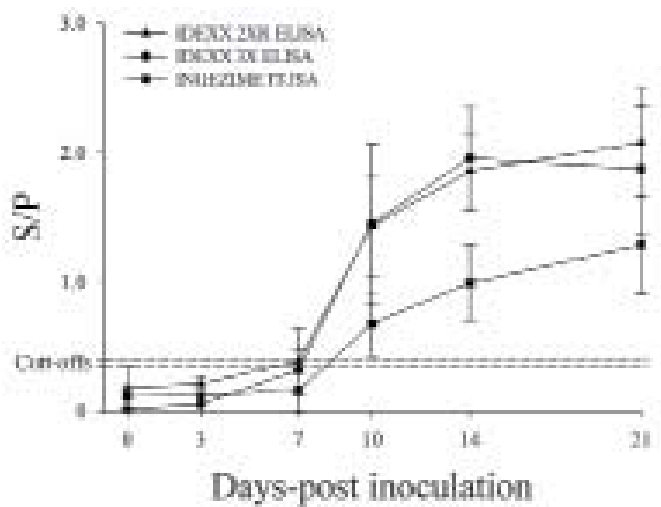

Figure 2. Cross-reactivity of PRRSV Lena experimental antisera with IDEXX 2XR ELISA, IDEXX 3X ELISA and INGEZIM ELISA PRRSV antigens. Symbols represent mean titres, whiskers above and below are standard deviations. IDEXX 2XR ELISA and IDEXX 3X ELISA s/p values lower than 0.4 were considered to be negative. An INGEZIM ELISA s/p value lower than 0.35 was considered to be negative

The genetic heterogeneity of PRRSV strains in Belarus which might influence the performance of serological assays is well documented [2,9]. In the present study, 249 field serum samples out of 269 field sera tested in IPMAs were positive in at least one of the assays. Out of 249 IPMA-positive field samples, 15\% were positive for antibodies against PRRSV LV antigens only and 4\% were positive for antibodies against PRRSV Lena antigens only. There were no samples positive for antibodies against PRRSV VR2332 antigens only. Therefore, it is possible that using LV, Lena or VR-2332 PRRSV strains alone as IPMA antigens for diagnostic purposes can provide false negative results. 
Afterwards, sera tested in the IPMAs were checked with the commercial IDEXX 2XR ELISA, IDEXX 3X ELISA and INGEZIM ELISA. A comparison of IPMA and ELISA results are represented in Table 1. The sensitivity of ELISAs varied from $80 \%$ to $86 \%$ (IDEXX 2XR ELISA-86\%, IDEXX 3X ELISA-80\% and INGEZIM ELISA-83\%). A failure to detect antibodies against subtype 3 PRRSV Lena (54\% of all false-negative ELISA tests were positive in IPMAs with PRRSV Lena as antigens), as well as higher serum sample dilutions $(1 / 40$ and $1 / 100$ in ELISAs versus $1 / 10$ in IPMAs) may both explain the lower sensitivity of commercial ELISAs.

Among IPMA-negative samples, ELISA-positive sera were also detected (Table 1). The IDEXX 2XR ELISA, IDEXX 3X ELISA and INGEZIM ELISA had 6 (specificity is $77 \%$ ), 4 (specificity is $83 \%$ ) and 6 (specificity is $77 \%$ ) unexpected positive results (out of $20 \mathrm{IPMA}^{-}$sera), respectively.

Table 1. Comparison of the IPMA and ELISA results (field sera)

\begin{tabular}{lccccccc}
\hline & & \multicolumn{2}{c}{ IDEXX 2XR ELISA } & \multicolumn{2}{c}{ IDEXX 3X ELISA } & \multicolumn{2}{c}{ INGEZIM ELISA } \\
\cline { 3 - 8 } & Total & positive & negative & positive & negative & positive & negative \\
\hline IPMA-positive & 249 & 207 & 42 & 188 & 61 & 197 & 52 \\
IPMA-negative & 20 & 6 & 14 & 4 & 16 & 6 & 14 \\
\hline
\end{tabular}

\section{DISCUSSION}

Since different heterologous PRRSV strains of the all known European subtypes circulate in Belarus, this region can be considered as a territory with an extreme PRRSV heterogeneity. Also, bacterial infections (Streptococcus suis, Escherichia coli) are endemic on many Belarussian swine farms. As a result, abortions, birth of mummified, dead and weak piglets, high mortality rate before weaning, respiratory disorders and mortality in growing pigs (up to $70 \%$ ) are common on swine farms (information from local veterinarians). In addition, a highly pathogenic East European subtype 3 PRRSV strain Lena (and probably other, yet unknown strains) circulates in Belarus [3]. Under these circumstances, testing of pigs for antibodies against PRRSV has a particular importance.

According to manufacturers, all commercial ELISAs tested in the present study are developed as a herd-screening tool. Thereunder, all swine farms included in the present study were ELISA-positive on the herd level, which coincides with the IPMA results. Consequently, all IPMAs and ELISAs provided valuable information about the farm PRRSV serological status. However, recognition of the individual animal serological status can be important during PRRSV eradication [14]. Applying IPMAs with only LV or only Lena PRRSV strains as antigens, or any of ELISAs resulted in missing of some positive field samples. Therefore, in the present study, none of the commonly used serological tools for PRRSV diagnosis may guarantee a flawless detection of antibodies at the individual animal level. Taking into account the heterogeneity of recently isolated PRRSV strains in different European countries [2,9,15-18], the problem might also be relevant in these territories. Immunoperoxidase monolayer assays which combine anti- 
gens of locally circulating PRRSV subtypes may provide the best performance.

Some unexpected positive ELISA results were observed among field sera which were negative in all IPMAs. Most probably, the results can be attributed to non-specific ELISA reactions, since the IPMAs are more sensitive upon testing experimental, as well as field sera. Field and experimental reports of non-specific reactions of the IDEXX 2XR ELISA are known [5,19]. Also in the present study, one serum collected from a negative pig prior PRRSV inoculation was positive in the IDEXX 2XR ELISA. Non-specific reactions of the IDEXX 3X ELISA and INGEZIM ELISA have not been reported yet. These findings have practical implementations, for example, if only a small number of sera is available from a farm, or only few positives are observed among tested samples, the ELISA results need to be cautiously interpreted. In this case, the findings can be confirmed by retesting with IPMAs.

In conclusion, none of the commonly used serological tools for PRRSV diagnosis can guarantee the flawless detection of antibodies at the individual animal level in regions with the extreme PRRSV heterogeneity. This fact should be taken into account during PRRS prevention and virus eradication, testing incoming pigs and monitoring PRRSVnegative herds in regions under a risk of being infected. Using IPMAs based on antigens of locally circulating PRRSV subtypes may provide the best performance under these circumstances.

\section{ACKNOWLEDGEMENTS}

The authors acknowledge Tamara A. Savelieva, Oleg P. Ivashkevich and Alexandr O. Sidorenko for their help in the sample collection in Belarus. The authors are grateful to Carine Boone and Chantal Vanmaercke for the excellent technical assistance. The research leading to these results has received funding from the European Union Seventh Framework Programme (FP7/2007-2013) under the grant agreement n ${ }^{\circ} 245141$.

\section{REFERENCES}

1. Mardassi H, Mounir S, Dea S: Identification of major differences in the nucleocapsid protein genes of a Québec strain and European strains of porcine reproductive and respiratory syndrome virus. J Gen Virol 1994, 75:681-685.

2. Stadejek T, Oleksiewicz MB, Scherbakov AV, Timina AM, Krabbe JS, Chabros K, Potapchuk D: Definition of subtypes in the European genotype of porcine reproductive and respiratory syndrome virus: nucleocapsid characteristics and geographical distribution in Europe. Arch of Virol 2008, 153:1479-1488.

3. Karniychuk UU, Geldhof M, Vanhee M, Van Doorsselaere J, Saveleva TA. Nauwynck HJ: Pathogenesis and antigenic characterization of a new East European subtype 3 porcine reproductive and respiratory syndrome virus isolate. BMC Vet Res 2010, 6:30.

4. Wensvoort G, Terpstra C, Pol JMA, ter Laak EA, Bloemraad M, de Kluyver EP, Kragten C, van Buiten L, den Besten A, Wagenaar F, Broekhuijsen JM, Moonen PLJM, Zetstra T, de Boer EA, Tibben HJ, de Jong MF, van ,t Veld P, Groenland GJR, van Gennep JA, Voets MT, 
Verheijden JHM, Braamskamp J: Mystery swine disease in the Netherlands: the isolation of the Lelystad virus. Vet Q 1991, 13:121-130.

5. Ferrin NH, Fang Y, Johnson CR, Murtaugh MP, Polson DD, Torremorell M, Gramer ML, Nelson EA: Validation of a blocking enzyme-linked immunosorbent assay for detection of antibodies against porcine reproductive and respiratory syndrome virus. Clin Diagn Lab Immunol 2004, 11:503-514.

6. Frey M, Eernisse K, Landgraf J, Pearson J, Chladek D: Diagnostic testing for SIRS virus at the Na-tional Veterinary Service Laboratory (NVSL). American Association of Swine Practitioners Newsletter 1992, 4:31.

7. Wensvoort G, de Kluyver EP, Luijtze EA, Besten DA, Harris L, Collins JE, Christianson WT, Chladek D (1992): Antigenic comparison of Lelystad virus and swine infertility and respiratory syndrome (SIRS) virus. J Vet Diagn Invest 1992, 4:134-138.

8. Wieczorek-Krohmer M, Weiland F, Conzelmann K, Kohl D, Visser N, Van Woensel P, Thiel HJ, Weiland E: Porcine reproductive and respiratory syndrome virus (PRRSV): monoclonal antibodies detect common epitopes on two viral proteins of European and U.S. isolates. Vet Microbiol 1996, 51:257-266.

9. Stadejek T, Oleksiewicz MB, Potapchuk D, Podgorska K: Porcine reproductive and respiratory syn-drome virus strains of exceptional diversity in Eastern Europe support the definition of new genetic subtypes. J Gen Virol 2006, 87:1835-1841.

10. Labarque GG, Nauwynck HJ, Van Reeth K, Pensaert MB: Effect of cellular changes and onset of humoral immunity on the replication of porcine reproductive and respiratory syndrome virus in the lungs of pigs. J Gen Virol 2000, 81:1327-1334.

11. Benfield DA, Nelson E, Collins JE, Harris L, Goyal SM, Robison D, Christianson WT, Morrison RB, Gorcyca D, Chladek D: Characterization of swine infertility and respiratory syndrome (SIRS) virus (isolate ATCC VR-2332). J Vet Diagn Invest 1992, 4:127-133.

12. Díaz I, Darwich L, Pappaterra G, Pujols J, Mateu E: Immune responses of pigs after experimental infection with a European strain of porcine reproductive and respiratory syndrome virus. J Gen Virol 2005, 86:1943-1951.

13. Rice AM, Plourde L, Muentener C, Liauw H, Leathers V: Performance of a new, singlewell format IDEXX PRRS ELISA diagnostic. International PRRS Symposium. Molecular, Immunological, Genetic and Epidemiological Approaches for PRRSV Control. Chicago Marriott, Downtown Magnificent Mile, Chicago, Illinois, 2009, p 106.

14. Dee SA, Bierk MD, Dee J, Molitor TW: An evaluation of test and removal for the elimination of por-cine reproductive and respiratory syndrome virus from 5 swine farms. Can J Vet Res 2001, 65:22-27.

15. Balka G, Hornyák A, Bálint A, Kiss I, Kecskeméti S, Bakonyi T, Rusvai M: Genetic diversity of por-cine reproductive and respiratory syndrome virus strains circulating in Hungarian swine herds. Vet Microbiol 2008, 127:128-135.

16. Frossard JP, Fearnley C, Naidu B, Errington J, Westcott DG, Drew TW: Porcine reproductive and respiratory syndrome virus: Antigenic and molecular diversity of British isolates and implications for diagnosis. Vet Microbiol 2012, 158:308-315.

17. Indik S, Valícek L, Klein D, Klánová J: Variations in the major envelope glycoprotein GP5 of Czech strains of porcine reproductive and respiratory syndrome virus. J Gen Virol 2000, 81:2497-2502. 
18. Stadejek T, Stankevicius A, Storgaard T, Oleksiewicz MB, Lenaák S, Drew TW, Pejsak Z: Identifica-tion of radically different variants of porcine reproductive and respiratory syndrome virus in Eastern Europe: towards a common ancestor for European and American viruses. J Gen Virol 2002, 83:1861-1873.

19. Horter DC, Pogranichniy RM, Chang CC, Evans RB, Yoon KJ, Zimmerman JJ: Characterization of the carrier state in porcine reproductive and respiratory syndrome virus infection. Vet Microbiol 2002, 86:213-228.

\title{
KARAKTERISTIKE DIJAGNOSTIČKIH TESTOVA ZA DOKAZIVANJE ANTITELA NA VIRUS REPRODUKTIVNOG I RESPIRATORNOG SINDROMA SVINJA U SERUMIMA SA FARMI SVINJA U REGIONU SA VELIKOM HETEROGENOŠĆU VIRUSA
}

\author{
KARNIYCHUK U Uladzimir, NAUWYNCK J Hans
}

Globalno najznačajnije oboljenje u svinjarstvu jeste reproduktivni i respiratorni sindrom svinja (PRRS). Virus, izazivač PRRS-a obuhvata dva različita genotipa: evropski i severnoamerički. Evropski genotip PRRS virusa je podeljen u tri subtipa: panevropski subtip 1 i istočnoevropski subtipovi 2 i 3 . Cilj ispitivanja je bio evaluacija karakteristika sa jedne strane komercijalnih i sa druge, seroloških testova koji su napravljeni u našoj laboratoriji, a u cilju testiranja seruma svinja iz različitih geografskih regiona sa ekstremno velikom heterogenošću PRRS virusa. S obzirom da u Belorusiji cirkulišu svi poznati evropski subtipovi PRRS virusa, ova je zamlja odabrana kao izvor uzoraka seruma svinja. Serumi poreklom sa farmi svinja iz Belorusije, ispitivani su metodom immunoperoksidaze u kulturi ćelija pri čemu su upotrebljeni antigeni: panevropskog subtip 1, istočnoevropskog subtip 3 i severnoameričkog soja uz primenu i komercijalne ELISA metode (IDEXX i INGEZIM). Dobijeni rezultati ukazuju da nijedna serološka metoda koja se koristi u dijagnostici PRRS virusa ne može da garantuje detekciju antitela na individualnom nivou. S obzirom na heterogenost nedavnih evropskih izolata PRRS virusnih sojeva, ovo može da bude značajno za veći broj zemalja. 